\title{
SOCIAL RESTRICTIONS IN THE COVID-19 PANDEMIC AS A TRAUMATIC EXPERIENCE: PSYCHOLINGUISTIC MARKERS
}

\author{
Natalia Kostruba \\ ORCID 0000-0002-3852-4729 \\ Scopus Author ID $\underline{57216884328}$ \\ nataliia.kostruba@vnu.edu.ua \\ Lesya Ukrainka Volyn National University, Ukraine
}

Received October 26, 2020; Revised June 16, 2021; Accepted June 18, 2021

\begin{abstract}
The COVID-19 pandemic has affected all aspects of life including psychological well-being. Social restrictions, changes in habits, and permanent stay at home might have a negative impact on the psychological state of people. The purpose of our study is to conduct a psycholinguistic analysis of pandemic narratives to identify markers of traumatic experience and identify possible gender differences. The sample consisted of 167 respondents ( $72 \%$ females). The mean age of participants was 21.09 years $(\mathrm{SD}=4.52)$. The study was conducted in Ukraine online in 2020, during the second wave of lockdown. The audience was asked to write a narrative on "How my life changed during the Covid-19 pandemic. Personal experience." As a result, we have found psycholinguistic markers that confirm the traumatic experience, among them are markers of time, depersonalization, and affective processes. A clear distinction of experience before and after the pandemic was detected in the narratives. This is characteristic of traumatic experience. In samples, such a distinction is made using the words "was" and "became". The psychological marker of affective processes indicates immersion in a traumatic event. This discomposure is reflected in the manifestation of negative emotions through the words "bad", "problems", "critical", and "difficult". The main semantic markers in pandemic narratives are time and life. The life marker was meaningfully represented by stories about social limitations and physical health. Distinctions in pandemic descriptions of men and women have been revealed as psycholinguistic and semantic markers are different. Narratives of women are larger, they use more words (pronouns, adverbs and conjunctions, interrogatives and quantifiers) than men. Regarding content, men are more likely to talk about affective processes, while women - about social and biological ones. Our study is a maiden attempt to reflect on the pandemic as a traumatic event within the collective experience.
\end{abstract}

Keywords: COVID-19 pandemic narrative, mental health, traumatic experience, psycholinguistic marker, women, men.

Коструба Наталія. Соціальні обмеження в пандемію Covid-19 як травматичний досвід: психолінгвістичні маркери.

Анотація. Пандемія COVID-19 вплинула не лише на усі сфери життєдіяльності, а й на психологічне благополуччя людини. Соціальні обмеження, зміна звичок, постійне перебування вдома усе це може мати негативний вплив на психологічний стан. Мета нашого дослідження здійснити психолінгвістичний аналіз наративів про пандемію у пошуках маркерів травматичного досвіду. Іншим завданням дослідження було виявити відмінності у психолінгвістичних та змістовних маркерах опису пандемії у чоловіків та жінок. Вибірку дослідження склали 167 респондентів, середній вік 21,09 років $(\mathrm{SD}=4,52), 3$ них 46 опитаних чоловічої та 121 жіночої статі. Дослідження проводилося онлайн у 2020 році, під час другої хвилі локдауну. Пропонувалось написати наратив на тему «Як змінилось Ваше життя під час

(C) Kostruba, Natalia, 2021. This is an Open Access article distributed under the terms and conditions of the Creative Commons Attribution 4.0 International Licence (http://creativecommons.org/licenses/by/4.0).

East European Journal of Psycholinguistics, 8(1), 28-40. https://doi.org/10.29038/eejpl.2021.8.1.kos 
пандемії Covid-19. Будь ласка, опишіть свій досвід розгорнуто». Загалом опрацьовано 167 наративів, кількість слів варіюється від 1 до 125. Аналіз наративів про пандемію дав можливість виявити психолінгвістичні маркери, які підтверджують травматичність такого досвіду. Серед них, маркер часу, деперсоналізації та афективних процесів. У наративах існує чітке розмежування досвіду на до і після, що характерне для травматичного досвіду. У описах таке розрізнення здійснюється з використанням слів було та стало. Психологічний маркер афективних процесів відображується у прояві негативних емоцій через слова погано, проблеми, критично, складно, що свідчить про зануреність у травматичну подію. Змістовний аналіз наративів дав можливість виявити основними маркерами - час і життя. У межах маркеру життя респонденти розповідали про соціальні обмеження та фізичне здоров'я. Виявлено відмінності у психолінгвістичних та змістовних маркерах опису пандемії у чоловіків та жінок. Наративи у жінок є більші за об'ємом, вони використовують більше стильових слів (займенники, прислівники і сполучники, interrogatives and quantifiers), ніж чоловіки. Змістовно, чоловіки частіше говорять про афективні процеси, жінки - про соціальні і біологічні процеси. Наше дослідження є тільки першою спробою осмислення пандемії як травматичної події у межах колективного досвіду.

Ключові слова: пандемічний наратив COVID-19, психічне здоров'я, травматичний досвід, психолінгвістичний маркер, жінки, чоловіки.

\section{Introduction}

COVID-19 is a medical disease that scientists are studying from a medical point of view with the focus on physical health. A pandemic and related stressors can also have serious consequences for mental and psychological health. It is normal to experience distress as a result of chronic stress of this magnitude. People were forced to change their way of life during the pandemic. They have experienced many real (death of someone close without the possibility of a ritual funeral) and symbolic (graduation ceremonies) shortage and losses. For many, such events can be unpleasant and some suffer from unspeakable grief. Social restrictions can lead to depression for many and suicidal thoughts for others (Okruszek et al., 2020).

Many researchers agree that the COVID-19 pandemic negatively affects the psychological state of people, causing symptoms of depression and anxiety (Dagnino, Anguita, Escobar, \& Cifuentes, 2020; Okruszek et al., 2020; Shuwiekh, Kira, \& Sous, 2020). Extensive study of psychological well-being in the United Kingdom has identified future clinical and research areas, one of which involves the study of social isolation and loneliness, emotional regulation, and coping strategies (Armor et al., 2020). In other words, the investigation of the manifestations and psychological consequences of social distancing and isolation in the COVID-19 pandemic is a relevant topic of study around the world.

COVID-19 is global pandemic, and most of the population is directly involved in related social distancing measures (physically distancing themselves from others, staying at home, limiting travel, using no-contact greetings, avoiding crowded areas). Aimed at slowing the rate of virus transmission, they have led not only to mistrust in the community but also to greater subjective isolation and, hence, to psychological distress (Bierman \& Schieman, 2020; Swader, 2019). Researchers claim that the pandemic has significantly affected the quality of social relations (Hussein, 2020). Longitudinal prospective studies demonstrate that social exclusion 
grows into a feeling of social isolation that stimulates negative cognitive processes (Dahlberg, Andersson, \& Lennartsson, 2018). Many scientists have argued that the comprehensive pandemic response should be introduced by governments in all countries (Griffin, 2020). Among the topical issues of the study is not only investigate the common traumatic reality of the COVID-19 pandemic but also the possibility of post-traumatic growth. (Bloomberg, 2021).

People differ in their genetics, neurodevelopment, general health, resilience, and protective factors and thus, may experience or understand the same pandemic differently. Determining who of them suffer from an injury requires identifying the appropriate consequences. For many, short-term trials will pass and never rise to the level of "trauma." For others, the effects will last a lifetime. In our study, we suggest to focus on the Straussner and Calnan's (2014) point of view. Scholars outline the concept of small- or micro-traumas as the more common traumas encountered by many of us. Such trauma often go unrecognized and unacknowledged. Yet these micro-traumas can cause severe mental pain and lifelong harm (Straussner \& Calnan, 2014). We consider forced social isolation in the COVID-19 pandemic as minor or microtrauma.

Demertzis and Eyerman (2020) have studied the COVID-19 pandemic as a cultural trauma affecting collective memory. American scientists such as Boyraz et al. (2020) have examined it through the prism of traumatic stress. They have found that social isolation and disease-related concerns could be important variables in reducing the traumatic stress associated with an outbreak of a disease.

The coronavirus pandemic is considered a collective trauma by the American psychologist Silver (2020). Polish researchers such as Łukianow et al. (2020) have found that when describing the experience of social isolation during a pandemic, people often referred to various "collective memories" in their diaries and drew parallels between the coronavirus pandemic and other periods of history. References to collective attitudes about coronavirus are an example of post-memory, the concept of which was first developed by Hirsch (2012). Even if the diary has no personal memories of the past, people use the basics known from historical interpretations of such events to give meaning to the pandemic period.

There are studies of the impact of social isolation on different age and social categories. For example, on pregnant women. The results confirm the negative consequences for the emotional state not only of the mother but also of her child (Jevitt, 2020). The effects of self-isolation in the pandemic on the older generation in neuroscience have been studied by Muntsant and Giménez-Llort (2020). Loneliness and social isolation in the long run are associated with a decline in the quality of life among older people (Beridze et al., 2020). Additionally, studies show that children and adolescents are more likely to experience high levels of depression and anxiety during and after forced isolation (Loades et al., 2020). Adolescent girls in social isolation feel a significant deterioration or lack of privacy (Baird et al., 2020).

There are not many studies of gender differences in the psychological consequences of a pandemic. According to research by Krupina et al. (2020), chronic stress of social isolation is a significant predictor of cognitive pathology, the 
scale of which may depend on gender. Straussner and Calnan's (2014) note that men and women experience trauma in very different ways and consequences. For instance, while men are much more likely to experience trauma, women are more likely to develop PTSD (Foa et al. 2009).

A theoretical review demonstrates that many researchers support the idea that social isolation in a pandemic is a traumatic experience. To study the psychological and linguistic features of experience, scientists often use the method of narratives (Rubin at al., 2019; Shaw at al., 2021). Davis et al. (2020) outline that expressive writing as one of the methods of overcoming emotional consequences or difficult circumstances arising from the COVID-19 pandemic (for example, loss of earnings, return to training and competition after a long break, etc.).

Our study aimed to identify psycholinguistic markers of the traumatic experience of the COVID-19 pandemic.

Research hypotheses:

- Narratives describing the experience of social constraints in a pandemic have psycholinguistic markers of the traumatic event.

- There are differences in psycholinguistic and semantic markers of pandemic description in men and women.

\section{Methods}

The study was conducted online in Ukraine in 2020, during the second wave of lockdown. The exact period of the survey was 22.10-22.12.2020. The sample was formed from students-volunteers of Lesya Ukrainka Volyn National University. Online survey was advertised by corporate mail of the university. As a result, 176 responses were received. After data cleaning, we took only 167 for further analysis. We did not take incomplete answers for consideration.

The sample consisted of 167 respondents. In general, 46 males and 121 females participated in the study. The mean age of participants was 21.09 years $(\mathrm{SD}=4.52)$.

The online survey consisted of 100 questions related to psychological wellbeing and coping COVID-19. The first task of the online survey was to write a narrative on "How did your life change during the COVID-19 pandemic." The audience was asked to describe their experience in detail. The material for the study was further investigated.

To perform psycholinguistic analysis, we used computer software Statistica 12 and Linguistic Inquiry and Word Count (LIWC 2015) (Pennebaker, Boyd, Jordan, \& Blackburn, 2015). The LIWC program is an effective method of studying the emotional, cognitive, and structural components present in verbal and written patterns of human speech. The program is actively used by scientists for applied research (Pennebaker et al., 2014). LIWC contains two blocks - software and dictionaries. English and German dictionaries are incorporated into the program simultaneously. The Ukrainian dictionary for the program was developed by Zasiekin (Zasiekin \& Rosenhart, 2018). 
So, to test Hypothesis 1, we used the LIWC 2015 program, the Pearson correlation coefficient (to identify the relationship between the number of words in the narrative and psycholinguistic categories) and singular value decomposition (SVD) word importance. To test Hypothesis 2, in addition to the methods already mentioned, we used t-test.

\section{Results}

A total of 167 narratives were processed. Statistically significant correlations between the number of words in the narrative and psycholinguistic categories are presented in Table 1.

Table 1.

Correlations Between the Number of Words in a Narrative and Psycholinguistic

Categories

\begin{tabular}{ll}
\hline & $\begin{array}{l}\text { Word } \\
\text { count }\end{array}$ \\
\hline Personal pronouns & $.265^{* *}$ \\
I & $.238^{* *}$ \\
Interrogatives & $.309^{* * *}$ \\
Social processes & $.246^{* *}$ \\
Cognitive processes & $-.216^{* *}$ \\
Affiliation & $.251^{* *}$ \\
Past focus & $-.198^{*}$ \\
Present focus & .051 \\
Future focus & .131 \\
Time & .037 \\
Religion & $.308^{* * *}$ \\
\hline Note. $*=\mathrm{p}<.05, * *=\mathrm{p}<.01, * * *=\mathrm{p}<.001$.
\end{tabular}

We obtained statistically significant correlations. The number of words in narratives is directly proportional to personal pronouns $(\mathrm{r}=.265 ; \mathrm{p}<.01), \mathrm{I}(\mathrm{r}=.238 ; \mathrm{p}<$ $.01)$, interrogatives $(\mathrm{r}=.309 ; \mathrm{p}<.001)$, social processes $(\mathrm{r}=.246 ; \mathrm{p}<.01)$, affiliation $(\mathrm{r}=.251 ; \mathrm{p}<.01)$, religion $(\mathrm{r}=.308 ; \mathrm{p}<.001)$. The number of words in the narrative is inversely interrelated with the indicators of cognitive processes $(r=-.216 ; \mathrm{p}<.01)$ and past focus $(\mathrm{r}=-.198 ; \mathrm{p}<.05)$. So, the greater the narrative, the more it is about communication and social connections, without reference to past experience. For example, "I stopped communicating with most people."; "It became more difficult to communicate with friends and acquaintances, most of them were afraid to touch each other so as not to accidentally become infected with the "deadly virus."; "Changed for the worse, many acquaintances are sick, interferes with learning and living together ..."; 
"Less contact with people. Because of this, communication with some stopped altogether."

The identified psycholinguistic markers as well as statistically significant gender differences in the demonstration of pandemic experience (t-test) and the correlations of psycholinguistic categories with gender are shown in table 2 .

Table 2.

The Results of Psycholinguistic Analysis of LIWC Experience of Social Constraints in a Pandemic, Gender Differences

\begin{tabular}{|c|c|c|c|c|c|c|c|c|}
\hline \multirow[b]{2}{*}{ Variables } & \multicolumn{2}{|c|}{ Total $(n=167)$} & \multicolumn{2}{|c|}{ Females $(n=121)$} & \multicolumn{2}{|c|}{ Males $(n=46)$} & \multirow[b]{2}{*}{$\mathrm{t}$} & \multirow[b]{2}{*}{$\mathrm{p}$} \\
\hline & Mean & $\begin{array}{l}\text { Standard } \\
\text { Error }\end{array}$ & Mean & $\begin{array}{l}\text { Standard } \\
\text { Error }\end{array}$ & Mean & $\begin{array}{l}\text { Standard } \\
\text { Error }\end{array}$ & & \\
\hline Word count & 15.08 & 1.36 & 16.79 & 1.50 & 10.57 & 2.87 & $1.96 *$ & $-.159 *$ \\
\hline $\begin{array}{l}\text { Personal } \\
\text { pronouns }\end{array}$ & 1.97 & .31 & 2.46 & .39 & .67 & .40 & $3.24 * *$ & $-.203^{*}$ \\
\hline $\begin{array}{l}\text { Impersonal } \\
\text { pronouns }\end{array}$ & 4.64 & 1.23 & 5.08 & 1.63 & 3.50 & 1.31 & .75 & -.044 \\
\hline $\begin{array}{l}\text { Common } \\
\text { Adverbs }\end{array}$ & 1.59 & .35 & 2.15 & .48 & .11 & .08 & $4.22 * * *$ & $-.200^{*}$ \\
\hline Conjunctions & 3.01 & .39 & 3.63 & .50 & 1.39 & .49 & $3.19 * *$ & $-.198 *$ \\
\hline Interrogatives & .98 & .19 & 1.25 & .25 & .26 & .20 & $3.10 * *$ & $-.179 *$ \\
\hline Quantifiers & .35 & .10 & .46 & .14 & .08 & .08 & $2.41 *$ & -.128 \\
\hline $\begin{array}{l}\text { Affective } \\
\text { processes }\end{array}$ & 2.75 & .75 & 1.67 & .43 & 5.61 & 2.46 & -1.58 & $.182 *$ \\
\hline $\begin{array}{l}\text { Positive } \\
\text { emotion }\end{array}$ & .79 & .29 & 1.05 & .40 & .11 & .10 & $2.28 *$ & -.111 \\
\hline $\begin{array}{l}\text { Negative } \\
\text { emotion }\end{array}$ & 1.13 & .63 & .45 & .15 & 2.90 & 2.23 & -1.09 & .136 \\
\hline Anxiety & .07 & .07 & .09 & .09 & .00 & .00 & 1.00 & -.048 \\
\hline $\begin{array}{l}\text { Social } \\
\text { processes }\end{array}$ & .94 & .18 & 1.14 & .22 & .41 & .25 & $2.15^{*}$ & -.142 \\
\hline $\begin{array}{l}\text { Cognitive } \\
\text { processes }\end{array}$ & 18.35 & 2.02 & 18.46 & 2.30 & 18.06 & 4.19 & .08 & -.007 \\
\hline $\begin{array}{l}\text { Biological } \\
\text { processes }\end{array}$ & .45 & .22 & .62 & .30 & .00 & .00 & $2.06^{*}$ & -.098 \\
\hline Past focus & 7.45 & .92 & 7.75 & 1.11 & 6.65 & 1.63 & .55 & -.041 \\
\hline Present focus & 1.90 & .37 & 2.30 & .47 & .87 & .48 & $2.13 *$ & -.135 \\
\hline Future focus & .13 & .06 & .18 & .08 & .00 & .00 & $2.30 *$ & -.109 \\
\hline Relativity & 73.83 & 1.74 & 74.22 & 1.89 & 72.80 & 3.93 & .33 & -.028 \\
\hline Motion & 3.94 & .76 & 4.07 & .93 & 3.61 & 1.30 & .28 & -.021 \\
\hline Space & 7.50 & .93 & 6.27 & .70 & 10.76 & 2.80 & -1.56 & $.167 *$ \\
\hline Time & 5.06 & .55 & 5.58 & .65 & 3.69 & 1.03 & 1.54 & -.118 \\
\hline Work & .71 & .32 & .98 & .45 & .00 & .00 & $2.20 *$ & -.105 \\
\hline
\end{tabular}

Note. $*=\mathrm{p}<.05, * *=\mathrm{p}<.01, * * *=\mathrm{p}<.001$.

Using t-test, we found statistically significant differences in the psycholinguistic characteristics of the narratives of men and women. Among the 
linguistic characteristics of the text revealed differences in indicators word count $(\mathrm{t}=1.96 ; \mathrm{p}<.05)$, personal pronouns $(\mathrm{t}=3.24 ; \mathrm{p}<.01)$, common adverbs $(\mathrm{t}=4.22 ; \mathrm{p}<$ $.001)$, conjunctions $(\mathrm{t}=3.19 ; \mathrm{p}<.01)$, interrogatives $(\mathrm{t}=3.10 ; \mathrm{p}<.01)$ and quantifiers $(\mathrm{t}=2.41 ; \mathrm{p}<.05)$. Differences among psychological processes in narratives relate to positive emotion $(\mathrm{t}=2.28 ; \mathrm{p}<.05)$, social processes $(\mathrm{t}=2.15 ; \mathrm{p}<.05)$, biological processes $(\mathrm{t}=2.06 ; \mathrm{p}<.05)$, present focus $(\mathrm{t}=2.13 ; \mathrm{p}<.05)$, future focus $(\mathrm{t}=2.30 ; \mathrm{p}<$ $.05)$, work $(\mathrm{t}=2.20 ; \mathrm{p}<.05)$. To refine the results, we also used a correlation analysis of all indicators with gender. Differences in the linguistic categories of narratives according to the results of t-test and correlation was coincided. We found correlations between gender and psychological categories such as affective processes $(r=.182 ; \mathrm{p}<.05)$ and space $(r=.167 ; \mathrm{p}<.05)$. Men more often than women in narratives turn to emotional expressions and discuss spatial constraints. For example, "There were certain difficulties of an emotional nature associated with relationships in the family"; "Life has become more complicated"; "The level of anxiety and tension a little increased".

To identify semantic narrative markers, we used singular value decomposition (SVD) word importance, which detects textual patterns in the data (Miner et al., 2012). SVD stand for the extent to which the individual words are represented or reproduced by singular values and, hence, how important the words are for defining the (latent semantic) space. We used SVD to detect semantic markers of pandemic description. The results of the analysis of meaningful markers of the pandemic experience as a traumatic event and the differences in these indicators by gender are shown in table 3.

Table 3.

Analysis of the Frequency of Use of Words and Their Weight (SVD Word Importance)

\begin{tabular}{|c|c|c|c|c|c|c|}
\hline \multirow[t]{2}{*}{ Stem / Phras } & \multicolumn{2}{|c|}{ Total $(n=167)$} & \multicolumn{2}{|c|}{ Females $(n=121)$} & \multicolumn{2}{|c|}{ Males $(n=46)$} \\
\hline & $\begin{array}{l}\text { Words } \\
\text { summary }\end{array}$ & $\begin{array}{l}\text { SVD word } \\
\text { importance }\end{array}$ & $\begin{array}{l}\text { Words } \\
\text { summary }\end{array}$ & $\begin{array}{l}\text { SVD word } \\
\text { importance }\end{array}$ & $\begin{array}{l}\text { Words } \\
\text { summary }\end{array}$ & $\begin{array}{l}\text { SVD word } \\
\text { importance }\end{array}$ \\
\hline було / was & 23 & 65.36 & 17 & 54.70 & 6 & 89.44 \\
\hline вдома / at home & 23 & 46.64 & 21 & 52.14 & 2 & 28.28 \\
\hline $\begin{array}{l}\text { дистанційно } \\
\text { /remotely }\end{array}$ & 17 & 42.22 & 13 & 40.84 & 4 & 48.99 \\
\hline друзі / friends & 24 & 51.62 & 24 & 60.75 & 0 & 0.00 \\
\hline дуже / very & 19 & 46.15 & 18 & 53.42 & 1 & 20.00 \\
\hline життя / life & 52 & 81.42 & 39 & 81.01 & 13 & 82.46 \\
\hline здоров'я / health & 13 & 36.65 & 11 & 40.27 & 2 & 28.28 \\
\hline $\begin{array}{l}\text { карантин / } \\
\text { quarantine }\end{array}$ & 14 & 35.12 & 11 & 36.23 & 3 & 34.64 \\
\hline $\begin{array}{l}\text { лікування / } \\
\text { treatment }\end{array}$ & 22 & 47.63 & 21 & 54.76 & 1 & 20.00 \\
\hline дальше / further & 38 & 71.80 & 34 & 78.51 & 4 & 48.99 \\
\hline
\end{tabular}




\begin{tabular}{lllllll}
\hline люди / people & 11 & 38.64 & 10 & 44.79 & 1 & 20.00 \\
менше / less & 20 & 45.42 & 20 & 53.85 & 0 & 0.00 \\
навчання / teaching & 18 & 54.08 & 11 & 36.90 & 7 & 87.18 \\
$\begin{array}{l}\text { обмеження / } \\
\text { limitation }\end{array}$ & 10 & 27.85 & 6 & 24.00 & 4 & 40.00 \\
$\begin{array}{l}\text { пандемія / pandemic } \\
\text { початок / beginning }\end{array}$ & 15 & 36.20 & 12 & 37.59 & 3 & 34.64 \\
$\begin{array}{l}\text { продовження / } \\
\text { соntinuation }\end{array}$ & 12 & 49.96 & 19 & 54.78 & 3 & 34.64 \\
$\begin{array}{l}\text { робота / work } \\
\text { стало / became }\end{array}$ & 10 & 28.09 & 7 & 28.34 & 3 & 34.64 \\
час /time & 42 & 72.12 & 37 & 79.56 & 5 & 44.72 \\
\hline
\end{tabular}

We found that the most important words in narratives about life changes during a pandemic for the entire sample were: "time" $(S V D=100.00)$, "life" $(S V D=81.42)$, "became"(SVD=72.12) and "further" (SVD=71.80). Respondents are concerned about the current situation and the possible continuation of quarantine restrictions and pandemics. We outlined differences in the importance of words in the narratives by gender. For men, words "was" (SVD=89.44) and "teaching" (SVD=87.18) more important. Men focused more on the past and on their studies (the sample was formed of students). For example, "Extremely sharp, because I was not ready for such a turn of events, but at the same time it was an interesting experience, such a thing has not been so long ago. There were times when I felt like a prisoner because there were restrictions on moving on the street, but it was not very difficult to survive". The results show that for women the words "became"(SVD=79.56), "less"(SVD=53.85), "further"(SVD=78.51), "friends"(SVD=60.75) are more important. Women talked more about current and future events, worried about the reduction of social contacts. For example, "My life has changed. Became less communication, less time with friends and godparents. You walk away from all people because everyone is potentially contagious".

\section{Discussion}

The study aimed to identify psycholinguistic markers of a traumatic event in the description of the pandemic experience. In addition, the target was to determine differences in psycholinguistic and meaningful markers of pandemic narratives in men and women.

We expected that narratives would have psycholinguistic markers of a traumatic event. Zasiekina et al. (2019) proposed psycholinguistic markers of traumatic memory, including the number of words in the narrative, the category of external agent, time, and place. In our study, we obtained relevant markers of pandemic narratives. Our results show that the number of words in narratives is negatively correlated with the focus on the past participle and cognitive processes. There is also a positive correlation between social category, religion, and the number of words in the narrative (see table 1). These results demonstrate that the 
larger the description of the experience of a pandemic, the less conscious and thoughtful it is. Some studies emphasize the important role of religiosity and social support in combating mental health problems (Kostruba, 2020).

Respondents describe the pandemic experience using pronouns and adverbs (for example, this, everyone, not at all), which serve as markers of depersonalization. The processed texts have high indicators of cognitive complexity (Table 2), which also confirms the high percentage of use of prepositions and conjunctions. We suggest this peculiarity demonstrates the attempt to make sense of the pandemic and its meaning using the words "was", "became", "carefully", "necessary", and so on.

Narratives are filled with words that indicate high rates of affective processes (Table 2), including negative emotions ("bad", "problems", "critically difficult"). High levels of emotionality of texts may indicate immersion in a traumatic event (Pennebaker et al., 2014; Uvarova, 2016). However, the levels of anxiety presented by respondents are quite low, which may be due to the long duration of the pandemic and the ability to adapt to new living conditions. In their descriptions of the pandemic experience, respondents focus on the past; there are no thoughts about the future. Hence, they point to the COVID-19 virus as close in space and time.

Another task of the study was to identify meaningful markers of narratives about the pandemic. Here it was found that the respondents turned more to the description of affective and social processes as well as focused on the temporal characteristics of their experience and space. SVD analysis revealed the main words most often used by respondents and their weight (display of text patterns). In such a way, the word "time" is the most frequent in narratives about a pandemic; it has the greatest meaning (Table 3). In describing the pandemic experience, there is a clear distinction between before and after. Respondents use the words "past" and "present", which are also often repetitive and meaningful. The division of life experience into time periods before and after the event is a confirmation of the trauma for a person (Schock et al., 2016). Thus, the frequency of words use "was","became" is a semantic indicator of the traumatic experience of a pandemic. Additionally, the words such as "the beginning" and "further" have a rather large meaning and frequency of use. Respondents are concerned about the protracted time of the pandemic and the fact that it will not end. That is, the audience does not know how the situation will unfold in the future and discuss the continuation of current events and the pandemic.

In addition to the findings already mentioned, the use of the word "life" is of great importance, which demonstrates the scale of the impact of the pandemic that has led to significant changes in all spheres of life. Of course, respondents are concerned about their physical condition, which is manifested in the frequent use of the words "treatment", "health", "quarantine". The narratives raise the issue of reducing the ability to communicate offline. Most often individuals denote such an experience with the words "less", "friends", "at home", "remotely", "restrictions". Also important is the topic of changing opportunities to study and work. 
The next task of our study was to identify differences in psycholinguistic and meaningful markers of the description of the pandemic in men and women. We found many statistical distinctions in psycholinguistic markers. Thus, in describing their experience, women are more verbose than men. For example, when describing the experience of a pandemic, women often use personal pronouns, adverbs, and conjunctions; interrogatives and quantifiers. For example, while "less" is frequently used in women's narratives, it is not recorded in men's ones at all.

However, men's narratives are more saturated with affective processes than women's (table 2). Namely, a positive correlation of the category of emotional processes with the male sex was revealed. They are more likely to use the words "bad", "problem", "security", and so on. Though, general comparison shows that the narratives written by women are more positively emotionally oriented.

Women to a greater extent than men in their narratives turned to social processes, namely, talking about friends and other people. While men are more concerned about the experience of studying and working in a pandemic.

In women's narratives, more attention is focused on biological processes. That is, they are more likely than men to discuss health and treatment because the cause of the pandemic is a reduction in the spread of the disease. In terms of time perspective, males in comparison to females hardly consider the present and the future, being focused on the past. Another confirmation of this thesis - the word "was" more often used by men.

\section{Conclusions}

Analysis of narratives on the pandemic made it possible to identify a set of psycholinguistic markers that confirm the trauma of such an experience. Among them are a marker of time, depersonalization, and affective processes. Narratives are aimed at discussing and assessing mainly past events; there is a clear distinction between the time span of life before and after, which is typical of traumatic experiences. Given that the pandemic continues, such a distinction in the descriptions is made using the words "was", "therefore", "continued", "further". The COVID-19 virus is defined as close in space and time. The psychological marker of affective processes is reflected in the manifestation of negative emotions through the words "bad", "problems", "critical", "difficult", which indicates immersion in a traumatic event. In general, the processed narratives have high indicators of cognitive complexity. However, the inverse relationship of this indicator with the number of words in the narrative was found. That is, not all respondents understood their life experience in a pandemic, which may indicate the trauma of such an experience.

A semantic analysis of narratives made it possible to identify the main markers - time and life. Respondents are focused on the duration of the pandemic, excited and waiting for it to end, as indicated by the frequent use of the words "beginning", "continuation", "further", and so on. A semantic marker of life indicates major 
changes in daily life due to the pandemic. Within this marker, respondents spoke about social limitations and physical health.

The study also aimed to identify differences in psycholinguistic and semantic markers of pandemic description in men and women. In general, females' narratives are larger; they use more words (pronouns, adverbs, and conjunctions; interrogatives; and quantifiers) than males'. In terms of content, the latter are more likely to discuss affective processes, using "bad", "problem", "security", and so on. Women are also more likely to concentrate on social and biological processes, namely referring to friends their health. While men are more concerned about the experience of studying and working in a pandemic, and they are more focused on how it was before the pandemic.

The study is only our first step towards understanding the pandemic as a traumatic event within the collective experience. Prospects for further study can be seen in expanding the study sample. It will be appropriate to identify differences in the traumatic experience the pandemic had on both those who were diagnozed with COVID-19 and those who were not. In addition, the study of the perception of time in different age groups in a pandemic seems promising.

\section{References}

Armour, C., McGlinchey, E., Butter, S., McAloney-Kocaman, \& K., McPherson, K. E. (2020).

The COVID-19 psychological wellbeing study: Understanding the longitudinal psychosocial impact of the COVID-19 pandemic in the UK; a methodological overview paper. Journal of Psychopathology and Behavioral Assessment, 43, 174-190. https://doi.org/10.1007/s10862020-09841-4

Baird, S., Alheiwidi, S., Dutton, R., Mitu, K., Oakley, E., Woldehanna, T., \& Jones N. (2020). Social isolation and disrupted privacy impacts of COVID-19 on adolescent girls in humanitarian contexts. Girlhood Studies, 13(3), 98-115. https://doi.org/10.3167/ghs.2020.130308

Bierman, A., \& Schieman, S. (2020). Social estrangement and psychological distress before and during the COVID-19 pandemic: Patterns of change in Canadian workers. Journal of Health and Social Behavior, 61(4), 398-417. https://doi.org/10.1177/0022146520970190

Beridze, G., Ayala, A., Ribeiro, O., Fernández-Mayoralas, G., Rodríguez-Blázquez, C., Rodríguez-Rodríguez, V., Rojo-Pérez, F., Forjaz, M.J., \& Calderón-Larrañaga, A. (2020). Are loneliness and social isolation associated with quality of life in older adults? Insights from Northern and Southern Europe. International Journal of Environmental Research and Public Health, 17(22), 8637. https://doi.org/10.3390/ijerph17228637

Boyraz, G., Legros, D.N., \& Tigershtrom, A. (2020). COVID-19 and traumatic stress: The role of perceived vulnerability, COVID-19-related worries, and social isolation. Journal of Anxiety Disorders, 76, 102307. https://doi.org/10.1016/j.janxdis.2020.102307

Bloomberg, S. (2021) Reflections on COVID-19, domestic violence, and shared trauma. In Tosone C. (ed.) Shared trauma, shared resilience during a pandemic. Essential Clinical Social Work Series. (pp. 69-77). Springer. https://doi.org/10.1007/978-3-030-61442-3_8

Dagnino, P., Anguita, V., Escobar, K., \& Cifuentes, S. (2020). Psychological effects of social isolation due to quarantine in Chile: An exploratory study. Frontiers in Psychiatry, 11, 591142. https://doi.org/10.3389/fpsyt.2020.591142 
Dahlberg, L., Andersson, L., \& Lennartsson, C. (2018). Long-term predictors of loneliness in old age: Results of a 20-year national study. Aging \& Mental Health, 22(2), 190-96. https://doi.org/10.1080/13607863.2016.1247425

Davis, P.A., Gustafsson, H., Callow, N., \& Woodman, T. (2020). Written emotional disclosure can promote athletes' mental health and performance readiness during the COVID-19 pandemic. Frontiers in Psychology, 11, 599925. https://doi.org/10.3389/fpsyg.2020.599925

Demertzis, N., \& Eyerman, R. (2020). Covid-19 as cultural trauma. American Journal of Cultural Sociology, 8, 428-450. https://doi.org/10.1057/s41290-020-00112-z

Foa, E. B., Keane, T. M., Friedman, M. J., \& Cohen, J. A. (Eds.). (2009). Effective treatments for PTSD: Practice guidelines from the International Society of Traumatic Stress Studies (2nd ed.). New York: Guilford Press.

Griffin, G. (2020). Defining trauma and a trauma-informed COVID-19 response. Psychological Trauma: Theory, Research, Practice, and Policy, 12(S1), S279-S280. http://dx.doi.org/10.1037/tra0000828

Hirsch, M. (2012). The generation of postmemory: Writing and visual culture after the holocaust. Columbia University Press.

Hussein, N.H. (2020). COVID-19 in a collectivist culture: Social isolation and maintenance of social relations. International Journal of Sociology and Social Policy. https://doi.org/10.1108/IJSSP-07-2020-0297

Jevitt, C. M. (2020). Covid-19 and intergenerational anxiety and trauma. Child \& Youth Services, 41(3), 280-282. https://doi.org/10.1080/0145935X.2020.1835163

Kostruba, N. (2020). Psychological features of relationship between religiosity and depression: Theoretical review of foreign studies. Habitus, 19, 66-70. https://doi.org/10.32843/2663$\underline{5208.2020 .19 .11}$

Krupina, N.A., Shirenova, S.D., \& Khlebnikova, N.N. (2020). Prolonged social isolation, started early in life, impairs cognitive abilities in rats depending on sex. Brain Sciences, 10(11), 799. https://doi.org/10.3390/brainsci10110799

Loades, M. E., Chatburn, E., Higson-Sweeney, N., Reynolds, S., Shafran, R., Brigden, A., Linney, C., McManus, M. N., Borwick, C., \& Crawley, E. (2020). Rapid systematic review: The impact of social isolation and loneliness on the mental health of children and adolescents in the context of COVID-19. Journal of the American Academy of Child and Adolescent Psychiatry, 59(11), 1218-1239.e3. https://doi.org/10.1016/j.jaac.2020.05.009

Łukianow, M., Głowacka, M., Helak, M., Kościńska, J., \& Mazzini, M. (2020). Poles in the face of forced isolation. A study of the Polish society during the Covid-19 pandemic based on 'Pandemic Diaries' competition. European Societies, S844-S858. https://doi.org/10.1080/14616696.2020.1841264

Miner, G., Elder, J., Fast, A., Hill, T., Nisbet, R., \& Delen, D. (2012). Practical text mining and statistical analysis for non-structured text data applications. Academic Press.

Muntsant A., \& Giménez-Llort L. (2020). Impact of social isolation on the behavioral, functional profiles, and hippocampal atrophy asymmetry in dementia in times of coronavirus pandemic (COVID-19): A translational neuroscience approach. Frontiers in Psychology, 11, 572583. https://doi.org/10.3389/fpsyt.2020.572583

Okruszek, Ł., Aniszewska-Stan'czuk, A., Piejka, A., Wis'niewska, M., \& Zurek, K. (2020). Safe but lonely? Loneliness, anxiety, and depression symptoms and COVID-19. Frontiers in Psychology, 11, 579181. https://doi.org/10.3389/fpsyg.2020.579181

Pennebaker, J.W., Boyd, R.L., Jordan, K., \& Blackburn, K. (2015). The development and psychometric properties of LIWC2015. University of Texas at Austin.

Pennebaker, J.W., Chung, C.K., Frazee, J., Lavergne, G.M., \& Beaver, D.I. (2014). When small words foretell academic success: The case of college admissions essays. PLoS ONE 9(12), e115844. https://doi.org/10.1371/journal.pone.0115844 
Rubin, D.C., Berntsen, D., Deffler, S.A., Brodar, K. (2019). Self-narrative focus in autobiographical events: The effect of time, emotion, and individual differences. Memory \& Cognition, 47, 63-75. https://doi.org/10.3758/s13421-018-0850-4

Schock, K., Böttche, M., Rosner, R., Wenk-Ansohn, M., \& Knaevelsrud, C. (2016). Impact of new traumatic or stressful life events on pre-existing PTSD in traumatized refugees: Results of a longitudinal study. European Journal of Psychotraumatology, 7. https://doi.org/10.3402/ejpt.v7.32106

Shaw, H., Robertson, S. \& Ranceva, N. (2021). What was the impact of a global pandemic (COVID-19) lockdown period on experiences within an eating disorder service? A service evaluation of the views of patients, parents/carers and staff. Journal of Eating Disorders, 9, 14. https://doi.org/10.1186/s40337-021-00368-x

Shuwiekh, H.A., Kira, I.A., \& Sous, M.S.F. (2020). The differential mental health impact of COVID-19 in Arab countries. Current Psychology, 1-15. https://doi.org/10.1007/s12144$\underline{020-01148-7}$

Silver, R. C. (2020). Surviving the trauma of COVID-19. Science, 369(6499), 11. https://doi.org/10.1126/science.abd5396

Straussner, S. L. A., \& Calnan, A. J. (2014). Trauma through the life cycle: A review of current literature. Clinical Social Work Journal, 42(4), 323-335. https://doi.org/10.1007/s10615014-0496-Z

Swader, C. S. (2019). Loneliness in Europe: Personal and societal individualism-collectivism and their connection to social isolation. Social Forces, 97(3), 1307-36. https://doi.org/10.1093/sf/soy088

Uvarova, S. (2016). Special features and dynamics of the mental states of personality in crisis conditions. Psychological Prospects Journal, 27, 257-268. https://doi.org/10.29038/22271376-2016-27-257-268

Zasiekin, S., \& Rosenhart, Y. (2018). Psycholinguistic computerized tools of linguistic and translation studies discourse analysis. Psycholinguistics, 23(2), 94-106. https://doi.org/10.5281/zenodo.1204994

Zasiekina, L., Kennison, S., Zasiekin, S., \& Khvorost, K. (2019). Psycholinguistic markers of autobiographical and traumatic memory. East European Journal of Psycholinguistics, 6(2), 119-133. https://doi.org/10.29038/eejpl.2019.6.2.zas 